INDUSTRIAL ECONOMICS: ISSUES AND PERSPECTIVES 


\section{Industrial Economics: Issues and Perspectives}

Paul R. Ferguson

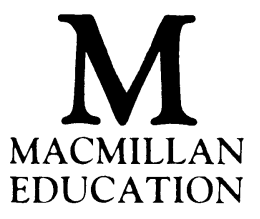


(C) Paul R. Ferguson 1988

All rights reserved. No reproduction, copy or transmission of this publication may be made without written permission.

No paragraph of this publication may be reproduced, copied or transmitted save with written permission or in accordance with the provisions of the Copyright Act 1956 (as amended), or under the terms of any licence permitting limited copying issued by the Copyright Licensing Agency, 33-4 Alfred Place, London WC1E 7DP.

Any person who does any unauthorised act in relation to this publication may be liable to criminal prosecution and civil claims for damages.

First published 1988

Published by

MACMILLAN EDUCATION LTD

Houndmills, Basingstoke, Hampshire RG21 2XS

and London

Companies and representatives

throughout the world

British Library Cataloguing in Publication Data

Ferguson, Paul R.

Industrial economics: issues and perspectives

1. Industrial organization (Economic theory)

I. Title

338 HD2326

ISBN 978-0-333-45950-8

DOI 10.1007/978-1-349-19211-3

ISBN 978-1-349-19211-3 (eBook) 


\section{Contents}

ACKNOWLEDGEMENTS vi vi

LIST OF ILLUSTRATIONS vii

LIST OF TABLES $\quad$ ix

PREFACE $\quad$ xi

1 INTRODUCTION 1

2 THE STRUCTURE-CONDUCT-PERFORMANCE

3 MARKET CONCENTRATION 23

4 THE ADVERTISING DEBATE 43

5 MONOPOLIES - GOOD OR BAD? 61

6 INVENTION, INNOVATION AND DIFFUSION 79

7 THE FOUNDATIONS OF INDUSTRY POLICY 101

8 INDUSTRY POLICY IN PRACTICE 121

9 STATE OR PRIVATE CONTROL? 143

$\begin{array}{lll}10 & \text { DEINDUSTRIALISATION } & 167\end{array}$

$\begin{array}{lll}11 & \text { CONCLUDING COMMENTS } & 187\end{array}$

$\begin{array}{lll}\text { APPENDIX } 1 & \text { THE DORFMAN AND STEINER CONDITION FOR } & 189 \\ & \text { OPTIMAL ADVERTISING LEVELS }\end{array}$

APPENDIX 2 HARBERGER'S METHOD OF ESTIMATING THE

WELFARE EFFECTS OF MONOPOLY 191

APPENDIX 3 COWLING AND MUELLER'S METHOD OF ESTIMATING THE WELFARE EFFECTS OF MONOPOLY 193

$\begin{array}{ll}\text { REFERENCES } & 195\end{array}$

$\begin{array}{ll}\text { INDEX } & 211\end{array}$ 


\section{Acknowledgements}

The author and publishers wish to thank the following who have kindly given permission for the use of copyright material:

The Advertising Association for material from European Advertising and Media Forecast

The Economist for material from 15 March 1986 issue of The Economist

Every effort has been made to trace all the copyright-holders, but if any have been inadvertently overlooked the publishers will be pleased to make the necessary arrangement at the first opportunity. 


\section{List of Illustrations}

2.1 The traditional SCP approach 10

2.2 More complex relationships between structure, conduct and performance 11

3.1 Comparison of concentration curves 24

3.2 Derivation of the Gini coefficient from the Lorenz curve 27

4.1 The optimal level of search 48

4.2 Advertising intensity and market concentration 49

4.3 Responsiveness of sales to level of advertising 51

4.4 The 'advertising as persuasion' view 52

4.5 The 'advertising as information' view 54

5.1 Reduction in economic welfare due to monopolisation 63

5.2 The effects on welfare of a monopoly with costs lower $\begin{array}{ll}\text { than in perfect competition } & 70\end{array}$

6.1 Ranking of firms in the United States market for ethical 81

6.2 Incremental product innovation under monopoly $\quad 87$

6.3 Process innovation in a perfectly competitive market 88

6.4 Process innovation in monopoly 89

6.5 Dynamic analysis of the welfare effects of innovation 90

6.6 Impact of a process innovation on factor employment in a
perfectly competitive industry

6.7 The time path of diffusion of a process innovation 94

7.1 The public good argument for market failure 105

7.2 The externality argument for market failure 107

9.1 Natural monopoly 145

9.2 Gains and losses from privatisation 155

10.1 The stages of economic growth 172 


\section{List of Tables}

2.1 Comparison of the structures of two hypothetical markets $\quad 10$

2.2 The characteristics of workable competition 18

3.1 Comparison of summary measures of market concentration

3.2 Comparison of aggregate concentration levels in manufacturing, 100-firm concentration ratios

3.3 Trends in seller concentration in major United States industries, 1963-77, four-firm concentration ratios calculated by value added

3.4 Average five-firm concentration ratios for the United Kingdom, with and without adjustment for international trade

3.5 Highly concentrated industries in the United Kingdom, 1983, before and after adjustment for international trade

4.1 Advertising as a percentage of GDP in selected countries

4.2 Advertising intensities by product groups in the United States, Brazil, and Mexico, 1972

4.3 Summary of the empirical evidence on the relationship between advertising and prices

4.4 Prices of the cheapest prescribed standard spectacles by country

5.1 Welfare changes due to monopolisation

5.2 Cowling and Mueller's estimates of welfare loss due to monopoly

5.3 Summary of empirical studies on the welfare effects of monopoly

5.4 Correlations between profits of United Kingdom industries, 1977-84

6.1 Research and development expenditures by industry as a percentage of sales and value added for selected United Kingdom industries, 1981

6.2 Research and development expenditures by industry as a percentage of sales for selected United States industries, 1975-83 
8.1 Competition powers of the European Community as given in the Treaty of Rome

8.2 Likelihood of prosecution under Department of Justice Merger Guidelines for the United States (1984)

9.1 Empirical evidence on the difference between state- and private-sector efficiency

9.2 Monopoly - state control and the privatisation options

10.1 Percentage of total employment in the industrial sector

10.2 Employment in the industrial sector (millions)

10.3 Index numbers of industrial production

10.4 Share of world manufacturing exports

10.5 Employment in services (millions)

10.6 Percentage of total employment in services

10.7 Share of total employment by type of service 


\section{Preface}

The industrial economics courses taught at the University of Lancaster have always been rather heretical. Philip Andrews and Elizabeth Brunner had an enduring belief in the strength of competition and were sceptical about the relevance of the 'structure-conduct-performance' (SCP) approach which dominated the subject. Harry Townsend, following the eclectic tradition of the London School of Economics, had a similar distaste for this paradigm, believing it to be too constraining. As long ago as 1972, he introduced transaction costs as a key element of the undergraduate industrial economics course, but even today this topic is ignored (or given scant attention) in many such courses elsewhere. Hence, as both a student and a lecturer at Lancaster, I have been made aware of alternative interpretations and approaches to the study of industrial economics which are only now beginning to receive wider recognition.

The Lancaster tradition of non-conformity is continued in this book, which differs in scope from other texts in the field of industrial economics. It covers the mainstream analysis, but challenges this approach - and the resulting policy conclusions - by introducing many of the less well-known developments in the area.

Without the help of many friends and colleagues, this book would have taken much longer to write. Andrea Pezzoli made many valuable comments while Harry Townsend gave enthusiastic support and help. Ron Bowen's lack of knowledge of economics, but careful attention to detail, removed much of the jargon. The boundless energy and enthusiasm of Professor Balasubramanyam led me to discover that I could work twice as hard as I had previously thought possible. My greatest debts are to Gerry Steele, who amazed me for his capacity meticulously to examine every draft I produced (and, furthermore, by his claim to enjoy such an onerous task) and to my wife, Glenys. As the book slowly advanced, she decided that the fastest way to rediscover leisure would be to help me. She finished up spending as long on the book as I did, and, in this sense, it is as much her effort as mine. Nevertheless, any remaining errors are my own responsibility.

This is the point where authors traditionally thank their secretary for her miraculous ability to decipher almost illegible handwriting; in this case thanks must go to my wordprocessor. Furthermore, I believe that I could 
have dispensed with the technical skills of the publisher and typeset the book myself. In fact, I could have performed all the publisher's tasks equally well, given the assumption that information is perfect, and in the absence of uncertainty and transaction costs. But if that were the case, there would also have been no need for me to write this book, and I would be doing a different job.

PAUL R. FERGUSON 